\title{
Documentation of the factors influencing the quality of coffee at farm level in south Karnataka
}

\author{
B.C. SHREEDEVI, M.K. SHWETHA AND ZAKEER KHAN
}

Received : 30.01.2015; Revised : 13.02.2016; Accepted : 14.03.2016

\begin{abstract}
Coffee occupies a place of pride among plantation crops grown in India. It is the most important cash crop that is grown in the tropics. Generally coffee is the second largest traded commodity next to petroleum products. Multistage random sampling method was adopted for the study to collect the necessary information from coffee growers and traders. Primarily the information regarding the quality attributes, constraints were collected from farmers. In Hassan district application of, shade regulation inorganic fertilizer and soil are influencing quality of coffee in per harvest practices. Type of coffee harvesting, drying method and after harvest storage are factors in the post-harvest which is influencing quality of coffee. Interrelationship among the factors like bean size, colour and roasting are correlated. Moisture content and storage, hulling and drying are having linkage between quality attributes. The main concern for the planters is labour availability which is also hindering the quality of coffee produced, so government should step forward and try solving this issue. In order to improve the quality of coffee, quality standards should be set not only for export trade and but also at the farm level. Most of the planters are not aware of many factors which influence the quality of coffee; planters should be trained and made knowledgeable by conducting the training program by government organization or by coffee Board.
\end{abstract}

KEY WORDS : Harvest practises, Documentation, Dendograph, Sorting, Grading

How to cite this paper : Shreedevi, B.C., Shwetha, M.K. and Khan, Zakeer (2016). Documentation of the factors influencing the quality of coffee at farm level in south Karnataka. Internat. J. Com. \& Bus. Manage, 9(1) : 24 -31.

MEMBERS OF THE RESEARCH FORUM

Correspondence to:

M.K. SHWETHA, Department of Agribusiness Management, College of Agriculture, University of Agricultural Sciences, DHARWAD (KARNATAKA) INDIA

Email: shwethamrutha@gmail.com

\section{Authors' affiliations:}

B.C. SHREEDEVI AND ZAKEER KHAN, Department of Agribusiness Management, College of Agriculture, University of Agricultural Sciences, DHARWAD (KARNATAKA) INDIA 